\title{
The obese child in the Intensive Care Unit. Update
}

\author{
Alejandro Donoso F., M.D., ${ }^{a}$ Pablo Córdova L., M.D., ${ }^{a}$ Pilar Hevia J., M.D., ${ }^{b}$ and \\ Daniela Arriagada S., M.D. ${ }^{a}$
}

\begin{abstract}
Given that childhood obesity is an epidemic, the frequency of critically-ill patients who are overweight or obese seen at intensive care units has increased rapidly. Adipose tissue is an endocrine organ that secretes a number of protein hormones, including leptin, whichstands out because it regulates adipose tissue mass. The presence of arterial hypertension, metabolic syndrome, diabetes mellitus, respiratory disease and chronic kidney disease may become apparent and complicate the course of obese pediatric patients in the Intensive Care Unit. Obesity management is complex and should involve patients, their families and the medical community. It should be coordinated with comprehensive government health policies and implemented in conjunction with a change in cultural context.

Key words: obesity, leptin, metabolic syndrome, hypertension, intensive care.
\end{abstract}

http:/ /dx.doi.org/10.5546/aap.2016.eng.258

\section{INTRODUCTION}

Discussions regarding obesity or overnutrition and their harmful effect on health have sparked off great interest but relatively small success in terms of the implemented prevention strategies. ${ }^{1,2}$

In developing regions, such as

a. Unit of Pediatric Critical Patients. Hospital Clínico Metropolitano La Florida. Santiago. Chile.

b. Department of Nephrology. Hospital San Juan de Dios. Santiago. Chile.

E-mail address:

Alejandro Donoso F., M.D.: adonosofuentes@gmail. com

\section{Funding:}

None.

Conflict of interest:

None.

Received: 7-1-2015

Accepted: 9-3-2015 Latin America, which is undergoing an epidemiological transition, the rate of obesity is high. More than $90 \%$ of childhood obesity is primary or exogenous, and caused by an excessive calorie intake in a setting of social determinants, such as poverty, lack of education and poor access to food. The remaining 10\% includes secondary or "endogenous" obesity, which may be caused by endocrine disorders, obesity-associated genetic defects, or hypothalamic damage conditions. $^{3}$

Child and adolescent obesity is a risk factor for several conditions and is associated with significant chronic morbidity (adult obesity) and early mortality. ${ }^{4,5}$ It has been reported that life expectancy is reduced between 5 and 20 years. ${ }^{6}$

Obesity is defined as excessive body fat (fat mass) in relation to height. At present, body mass index (BMI), calculated as weight $(\mathrm{kg}) / \mathrm{square}$ of height $\left(\mathrm{m}^{2}\right)$, is the recommended and most widely accepted indicator to assess the extent of obesity in the pediatric population, ${ }^{7}$ both in the clinical and the epidemiological setting.

The following BMI cut-off values are recommended for children and adolescents aged 2 to 19 years old: ${ }^{8}$

- Z score between 1 and 2 or percentile 85-96: overweight.

- $Z$ score $\geq 2$ or percentile $\geq 97$ : obesity.

- $Z$ score $\geq 3$ : severe obesity.

An individual weight/age and height/age assessment is recommended for infants.

The objective of this review is to offer, from an intensivist's perspective, an update on the pathophysiology of obesity and the main relevant comorbidities that may be present or develop in obese patients during their stay in the Intensive Care Unit (ICU).

\section{Epidemiology}

The prevalence of overweight and obesity among children and adolescents is increasing worldwide and has become an epidemic. For example, in the United States of America, $16.5 \%$ of 6 -to- 19 year-old children are overweight, and $17 \%$ are obese. ${ }^{9}$

Such increase in childhood obesity has also taken place in developing countries, and has even tripled in Chile between the 1970s and the 1990s. ${ }^{10}$

A recent systematic review ${ }^{11}$ reported that $20-25 \%$ of Latin American children and adolescents (aged 0-19 years old) were overweight or obese. 
The results of the National Survey on Nutrition and Health (Encuesta Nacional de Nutrición y Salud, ENNyS) indicated an obesity prevalence of $10.4 \%$ in children aged between 6 and 60 months old. In addition, the rate of overweight and obesity increased with age and reached 20\%. This also varies by geographic region and socioeconomic status. This situation is concurrent with deficit conditions. ${ }^{12}$

In Argentina, it has been recently reported that for a population of 13-to-15 year-old adolescents, the prevalence of overweight had increased, over a five-year period, from $24.5 \%$ to $28.6 \%$, while that of obesity went from $4.4 \%$ to $5.9 \% .{ }^{13}$ Also in Argentina, overweight or obesity were described as being $45 \%$ among 4 year-old children, with a high percentage of alterations in body fat distribution pattern. ${ }^{14}$

Likewise, in Chile, a prospective study in children and adolescents aged 2-18 years old described that $13.9 \%$ were overweight and $12 \%$, obese, with no differences by sex or age group. ${ }^{15}$

The origin of obesity involves many factors and is correlated to genes and lifestyle. ${ }^{16,17}$ Some factors, such as consuming processed foods and sugar-sweetened beverages, together with a sedentary lifestyle, contribute to said increase..$^{18}$

A recent European population-based study conducted in 3000 children from birth to 5 years old assessed the association between genetic predisposition and obesity. An association between genotype variations and the extent of growth and body composition since the first year of life was identified, but not in the prenatal stage. ${ }^{19}$ These findings suggest a greater susceptibility to developing obesity during adulthood.

Finally, childhood obesity complications not only become apparent during adulthood as chronic conditions, but they have early consequences, such as arterial hypertension, ${ }^{20}$ hyperlipemia ${ }^{21}$ obstructive sleep apnea (OSA), ${ }^{22}$ and asthma worsening. ${ }^{23}$

Given that the frequency of obese children has increased in the general population and due to its associated comorbidities, the prevalence of obese children has also increased in intensive care units and hospital wards. At the same time, an increased prevalence of hospitalized obese children has been described, reaching up to $20 \%{ }^{24}$

\section{Pathophysiology of obesity Leptin biology}

Obesity is a multifactorial disease with several pathophysiological mechanisms involved, either in relation to weight control and energy expenditure and related comorbidities.

Adiposity hormones are called adipokines and include leptin, a hormone made up of 167 amino acids and similar to cytokines, that is mainly synthesized by adipocytes of white fat and coded in the Lep gene, located on chromosome $7 q 31.3 .^{25-}$ ${ }^{27}$ Once leptin is secreted and reaches the systemic circulation (in proportion to the magnitude of body fat depot), it binds to specific cell surface receptors and activates intracellular signaling pathways. ${ }^{28}$ The leptin receptor gene (LepR) is a member of the type I cytokine receptor family and codes six leptin receptor isoforms. ${ }^{28}$ Only LepRb has structural elements necessary for intracellular signal transduction. ${ }^{26,29}$ LepRb is expressed in different neuronal groups of the central nervous system (CNS), mainly the hypothalamus, where it regulates the expression of neuropeptides involved in eating habit adjustment, in addition to thermogenesis and fertility. On a peripheral level, it directly affects the metabolism and functioning of adipocytes, lungs, kidneys, muscles, skeleton, liver, adrenal cortex, and pancreatic $\beta$ cells, among others.

Childhood obesity is correlated to an increased leptin circulating level. ${ }^{30,31}$ Leptin plays an immunomodulatory role ${ }^{32}$ and develops, in these patients, a low-grade chronic inflammation, ${ }^{33}$ which is associated with macrophage infiltration into adipose tissue. This leads to increased proinflammatory cytokine levels, such as tumor necrosis factor- $\alpha$, interleukin- $1 b$, interleukin-6, and this situations contributes to insulin resistance ${ }^{34}$ and a reduced immune and metabolic reservoir. ${ }^{35,36}$ Thus, insulin resistance, hypercoagulability and inflammation characterize obesity as a condition that is similar to a critical disease. $^{37}$

Clinical implications are relevant because the inflammatory response of an obese child is different from that of a non-obese child.

\section{Comorbidities in obese children}

As it occurs with adults, several comorbidities are secondary to increased abdominal fat, such as insulin resistance, metabolic syndrome, arterial hypertension, dyslipemia and type 2 diabetes mellitus (T2DM), and are associated with a greater waist circumference and obesity in pediatric patients. ${ }^{38,39}$ These conditions may be diagnosed upon admission to the ICU and have an impact on the prognosis of the critically-ill pediatric patient (Figure 1). 
Another chronic condition associated with childhood obesity is atherosclerotic cardiovascular disease. It has been demonstrated that hyperleptinemia in the adolescent population is associated with a lower arterial distensibility, which is a relevant functional index for atherosclerosis. ${ }^{40}$ Hyperleptinemia is an independent factor for cardiovascular risk and, among others, for coronary artery atherosclerosis risk. It is a mediator of endothelial dysfunction and neointimal hyperplasia and causes a paracrine effect of perivascular adipose tissue over the smooth muscle. ${ }^{41}$ Among obese children, the intima-media layers are thicker; this is a noninvasive marker of early atherosclerotic changes. It has been demonstrated that this condition may be reversed through BMI normalization during childhood. ${ }^{42}$

Data evaluating differences in mortality between obese and non-obese cohorts are not conclusive. ${ }^{43}$
During the recent influenza A (H1N1) epidemic, obese children had a worse clinical course. ${ }^{44}$

A recent report indicated that obese children requiring invasive mechanical ventilation did not show a higher mortality nor did they require a longer stay on mechanical ventilation support. ${ }^{45}$ On the contrary, it has been reported that obese patients with severe trauma ${ }^{46}$ or burn ${ }^{47}$ have more complications and a longer stay in the ICU. Many complications in trauma patients are related to existing conditions or premorbidities. ${ }^{46}$

Evidence suggests that childhood obesity is associated with a lower survival rate after inhospital cardiac arrest. ${ }^{48}$ This has led to proposing a review of effectiveness of drugs exclusively based on body weight. ${ }^{49}$ Thus, highly watersoluble drugs with a small distribution volume (e.g., epinephrine) may reach high plasma levels in obese children and be potentially unsafe. ${ }^{50}$ Conversely, highly lipid-soluble drugs (e.g.,

FIGURE 1. Medical and psychosocial problems observed in childhood and adolescent obesity

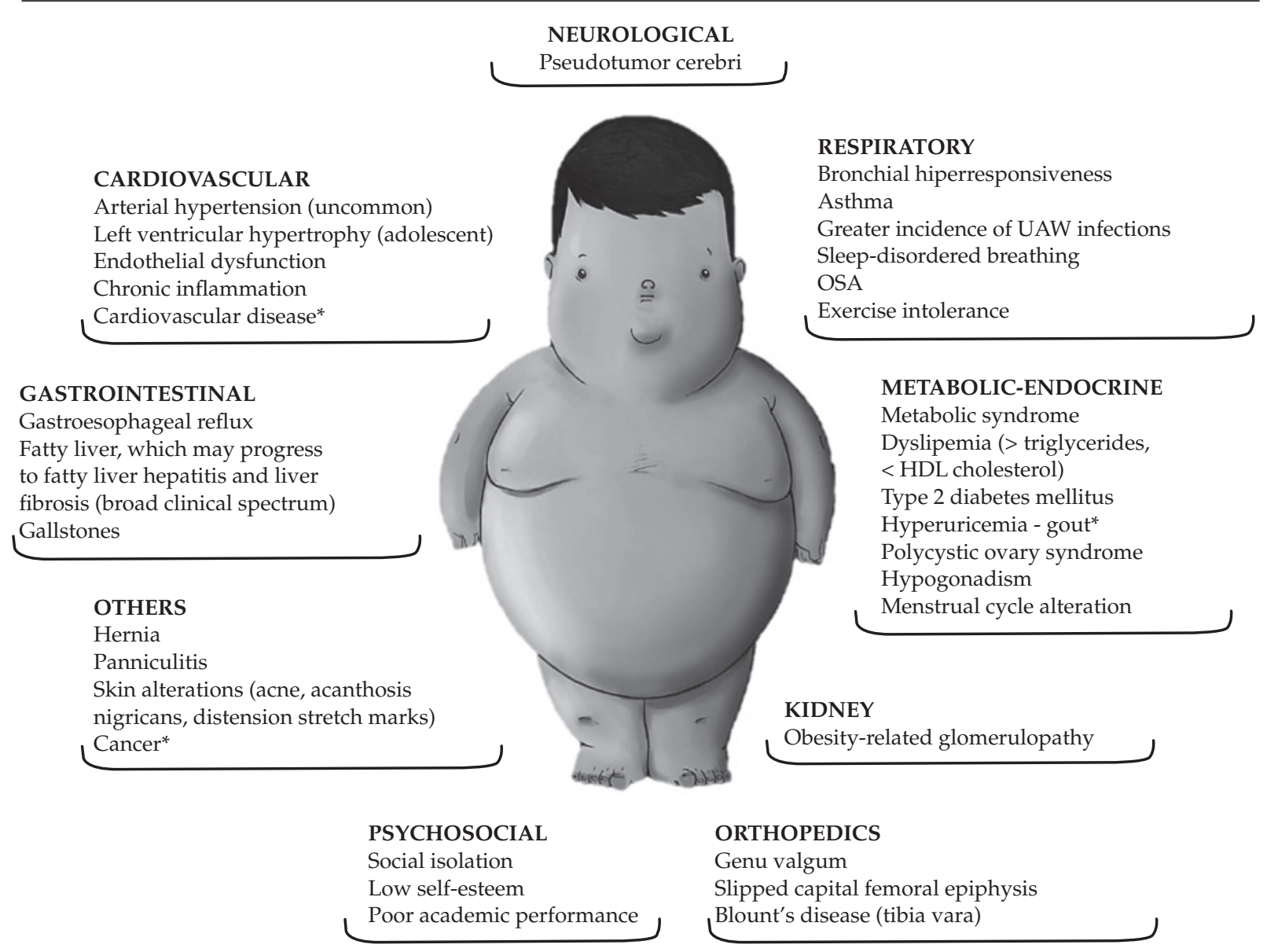

UAW: upper airway; OSA: obstructive sleep apnea. * Late complications. 
amiodarone) have a large distribution volume in obese patients and higher doses may be required to achieve a comparable effect. ${ }^{51}$ It has been recommended that defibrillation doses should be reviewed, ${ }^{52}$ as well as standard chest compression techniques.

An increased BMI causes a higher cardiovascular, respiratory and metabolic effort, which results in a significant decline in the physiological reserve. During aerobic performance assessment, it has been demonstrated that such response leads to a reduced cardiorespiratory efficiency in obese children. ${ }^{53,54}$

Among children with acute lymphoblastic leukemia, regardless of existing therapeutic response predictors, obesity has been associated with a poor vital prognosis. ${ }^{55}$

Finally, further studies are required to estimate the actual impact of obesity on the course and prognosis of critically-ill children.

\section{Metabolic syndrome}

Overweight and obesity are associated with a greater prevalence of several factors of cardiovascular risk. ${ }^{56}$ Metabolic syndrome (MS) is the name for a set of several metabolic anomalies, each an independent risk factor of cardiovascular disease and diabetes, and that together cause a synergistic effect. ${ }^{8}$ There are different criteria regarding MS in pediatrics. Criteria applied to adults are extrapolated to children upon adjustment by age and sex. In clinical practice, it is recommended to use Cook's criteria. ${ }^{57}$ For the diagnosis of MS, three out of five criteria should be met: waist circumference $\geq 90^{\text {th }}$ percentile, fasting glucose $\geq 110 \mathrm{mg} / \mathrm{dL}$, triglycerides $\geq 110 \mathrm{mg} / \mathrm{dL}$, HDL cholesterol $<40$ $\mathrm{mg} / \mathrm{dL}$, blood pressure $\geq 90^{\text {th }}$ percentile.

Excess central (intra-abdominal) fat is related to cardiovascular disease and T2DM during adulthood. ${ }^{58}$ An assessment of anthropometric indicators, such as waist/height ratio, helps to establish cardiometabolic risk in the pediatric population. .9960

An association between overweight, insulin resistance and MS has been established among school children. ${ }^{61}$ It has been reported that between $30 \%$ and $50 \%$ of obese adolescents have MS, compared to $7 \%$ of overweight adolescents and $0.6 \%$ of those with a normal BMI. ${ }^{62,63}$

Stress-induced hyperglycemia, common in critically-ill patients, may be more marked among obese children and adolescents. Hyperglycemia, which may be initially considered beneficial (higher substrate to tissues with increased demand), if prolonged over time, it may lead to the formation of free radicals, cellular damage and immune alterations, resulting in an eventual worse prognosis. ${ }^{64}$ However, there are no clear data on the relationship between glycemic control and prognosis of critically-ill patients. ${ }^{65,66}$ A subgroup of these children may develop T2DM with mild symptoms, therefore delaying diagnosis. In addition, it may appear as hyperglycemic-hyperosmolar state (4\%), an uncommon condition that has a significant morbidity and mortality ${ }^{67-69}$

\section{Arterial hypertension}

The worldwide epidemic of childhood obesity has led primary arterial hypertension to become, at present, one of the more common causes of hypertension in children and adolescents. ${ }^{70}$

Obesity is an independent risk factor for arterial hypertension in pediatrics. ${ }^{71-74}$ Obese patients have endothelial and vascular smooth muscle dysfunction, ${ }^{73}$ as well as a reduced parasympathetic nervous activity. ${ }^{75,76}$ Arterial hypertension has been associated with a larger left ventricular mass in obese children. ${ }^{74}$ Severe uncontrolled hypertension may lead to early organ damage..$^{77,78}$

\section{Pulmonary physiology}

Data on the impact of obesity on pulmonary physiology in the pediatric population are limited. It has been reported that the most prevalent alterations in lung function are a reduced functional residual capacity (FRC) and compromised diffusion..$^{79}$ Overweight is also associated with a general reduction in lung volume, which may be reflected in a worse functional capacity. ${ }^{80}$

A recent study in overweight school children and adolescents described that, in the absence of respiratory symptoms, $65 \%$ of them had an abnormal pulmonary function. Obstructive ventilatory defect and positive bronchodilator response were the most common abnormalities. ${ }^{81}$ Among children, the effects of adiposity on lung function depend on sex and BMI. ${ }^{82}$

\section{Airways}

Intensivists should be trained in airway management, be ready to request assistance and have access to the necessary equipment for difficult airway intubation. ${ }^{83} \mathrm{~A}$ recent report assessed the impact of obesity as a risk factor for 
respiratory adverse events during procedural sedation and indicated that these patients more commonly required airway interventions. ${ }^{84}$

It is known that classical anatomic airway landmarks are not evident, so management is challenging. ${ }^{85}$ The airway is characterized by a small oral cavity with redundant oropharyngeal tissue, hypertrophic tonsils and/or adenoids and a thick, short neck with little mobility; there is also fatty infiltration in the muscles, which causes a direct airway narrowing. All such anatomic factors may complicate visualization during a laryngoscopy ${ }^{86,87}$ This scenario may even become more complicated due to the difficulty to maintain a patent airway before endotracheal intubation, problems to manage ventilation with a face mask and a quick desaturation caused by a lower FRC (presence of atelectasis in dependent regions), ${ }^{88,89}$ which is the result of a reduced expiratory reserve volume; all this affects obese patients' capacity to tolerate extended apnea periods $s^{90}$ and, in the end, the period before oxygen arterial desaturation is brief. ${ }^{91}$

Among adults, neither obesity nor BMI were associated with a predicted difficult intubation. ${ }^{92}$ Measuring neck circumference in children is a useful and easy technique during screening and has been associated with respiratory adverse events..$^{93}$

\section{Bronchial asthma}

Bronchial asthma has been described in 30\% of overweight and obese patients ${ }^{94}$ and is more prevalent and severe with an increasing body weight. ${ }^{23,95,96}$ Serum leptin levels are positively correlated to BMI and the prevalence of atopic asthma among children. ${ }^{97}$

Obese asthma patients require a longer stay at the ICU because they recover more slowly than non-obese patients with a similar severity status upon admission. ${ }^{23}$

\section{Sepsis in obese patients}

Obesity is associated with immune disorders, but its effect on the predisposition and prognosis of sepsis patients has not been clearly established. ${ }^{98,99}$ However, there is cumulative evidence that obese patients are more prone to having severe complications from common infections. ${ }^{100,101}$

In an experimental cecal ligation and puncture (CLP) model of sepsis in mice, diet was modified briefly to induce obesity and assess inflammatory response. The model demonstrated that mice had a lower chance of survival and greater organ damage, which was dependent on changes in nuclear factor- $\kappa B .{ }^{102}$ However, a recent experimental model of sepsis in obese mice showed that hyperleptinemia improved survival and immune response. ${ }^{103}$

\section{Effects of obesity on the kidneys}

Observational studies have shown that obesity is a potential risk factor for renal disease of various origins, predominantly chronic kidney disease, but also kidney stones and renal cell carcinoma. ${ }^{104}$ Over the past decades, a significant increase in obesity-associated glomerulopathy has also been described, and this is a condition that is exclusively related to excess weight. ${ }^{105}$

In addition to the known relationship between MS and the development of T2DM and cardiovascular disease, ${ }^{58}$ there is evidence of a significant relationship between MS and obesity and albuminuria and end-stage renal disease (ESRD), ${ }^{106-108}$ which has been observed to appear early in youth. ${ }^{109}$

It has been proposed that adipocytes are the driving force of glomerular hyperfiltration in obese patients (Figure 2). As previously mentioned (see above), adipose tissue is a source of specific proteins (leptin, resistin, adiponectin), inflammatory mediators, oxidative stress generators ${ }^{110}$ and components of the reninangiotensin-aldosterone (RAA) system, all these factors have a direct effect on obesity-associated kidney disease. ${ }^{111,112}$ In addition, renal hilum compression by visceral fat and increased intraabdominal pressure have been attributed a role in the RAA axis activation. ${ }^{113}$

Leptin binds to glomerular and mesangial endothelial receptors and stimulates cell proliferation (mesangial-glomerular expansion), synthesis of transforming growth factor $\beta-1$, production of type I and IV collagen, and glucose transport. ${ }^{114}$ Then, paracrine communication between endothelial and mesangial cells allows leptin to promote an extracellular matrix depot, which in the end causes glomerulosclerosis and concomitant tubulointerstitial injury. It is also worth remembering that MS causes changes in urine composition, with increased levels of uric acid, oxalate and calcium, and a reduction in citrate level, which leads to stone formation. ${ }^{115}$

\section{CONCLUSIONS}

Adipose tissue is an endocrine organ that produces several protein hormones. One of 
the most common hormones is leptin, whose circulating levels are increased in obese children. Obesity in pediatric patients causes significant pathophysiological effects on different organs and systems and associated conditions, such as chronic inflammation, asthma, arterial hypertension, type 2 diabetes mellitus and chronic kidney disease.

Upon admission to the Intensive Care Unit for varying conditions, obese pediatric patients have a greater number of comorbidities, and this is an additional reason why the medical community and the society should unite to provide effective prevention measures and management to susceptible families.

\section{REFERENCES}

1. Hofmann B. Bariatric surgery for obese children and adolescents: a review of the moral challenges. BMC Med Ethics 2013;14:18.

2. Peirson L, Fitzpatrick-Lewis D, Morrison K, Ciliska D, et al. Prevention of overweight and obesity in children and youth: a systematic review and meta-analysis. CMAJ Open 2015;3(1):E23-33.

3. Mason K, Page L, Balikcioglu PG. Screening for hormonal, monogenic, and syndromic disorders in obese infants and children. Pediatr Ann 2014;43(9):e218-24.

4. Yanovski JA. Pediatric obesity. Rev Endocr Metabol Disord 2001;2(4):371-83.

5. Must A, Phillips SM, Naumova EN. Occurrence and timing of childhood overweight and mortality: findings from the Third Harvard Growth Study. J Pediatr 2012;160(5):743-50.

6. Fontaine KR, Redden DT, Wang C, Westfall AO, et al. Years of life lost due to obesity. JAMA 2003;289(2):187-93.

FIGURE 2. Relationship among obesity, insulin resistance/compensatory hyperinsulinemia, metabolic syndrome components and kidney damage, chronic kidney disease, end-stage renal disease, and cardiovascular disease

\section{Obesity \\ - Genetic factors \\ - Environmental factors (diet, physical activity)}
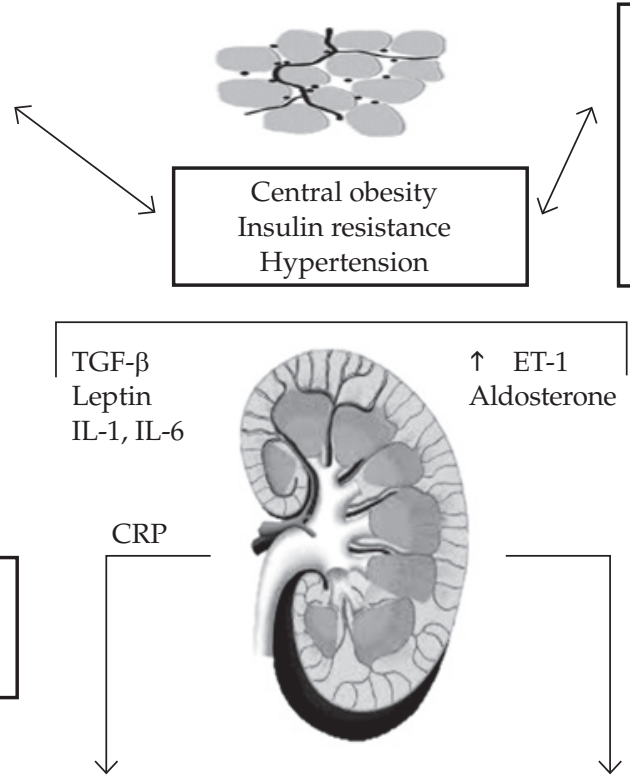

$\uparrow \quad$ ET-1

Aldosterone

Adipose tissue dysfunction

- Increased adipokine production

- Low-grade inflammation

- IL-1,6, TNF- $\alpha$

- Increased RAS

- Reduced adiponectin $\uparrow \quad$ PAI- $1 /$ TPA

(altered fibrinolysis, vasoconstriction) $\uparrow$ Oxidative stress

- Angiotensin II/AT1R

- NADPH oxidase

- ROS production

$\uparrow \mathrm{NO} \rightarrow \mathrm{ONOO}^{-}$ $\uparrow \quad$ Systemic and renal RAAS activation

$\uparrow \quad$ Fibrosis
Reduced NO production Endothelial dysfunction

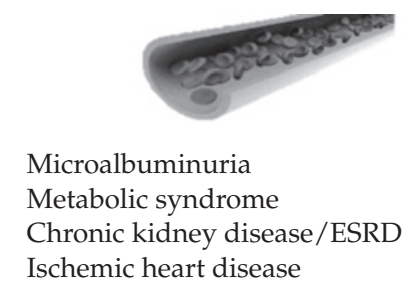

Insulin resistance and compensatory hyperinsulinemia cause renin-angiotensin system (RAS) activation, oxidative stress, low-grade chronic systemic inflammation, glomerular hypertension, microalbuminuria, and matrix expansion and fibrosis. AT1R: angiotensin II type I receptor; CRP: C-reactive protein; ESRD: end-stage renal disease; ET-1: endothelin-1; IL: interleukin; NADPH: nicotinamide adenine dinucleotide phosphate; NO: nitric oxide; PAI-1: plasminogen activator inhibitor-1; ROS: reactive oxygen species; TGF- : transforming growth factor- ; TNF- : tumor necrosis factor- ; tPA: tissue plasminogen activator; RAAS: renin-angiotensin-aldosterone system; ONOO-: peroxynitrite. 
7. Lobstein T, Baur L, Uauy R. Obesity in children and young people: a crisis in public health. Obes Rev 2004;5(Suppl 1):4-104.

8. Comité Nacional de Nutrición. Guías de práctica clínica para la prevención, el diagnóstico y el tratamiento de la obesidad. Arch Argent Pediatr 2011;109(3):256-66.

9. Ogden CL, Carroll MD, Curtin LR, McDowell MA, et al. Prevalence of overweight and obesity in the United States, 1999-2004. JAMA 2006;295(13):1549-55.

10. Wang Y, Lobstein T. Worldwide trends in childhood overweight and obesity. Int J Pediatr Obes 2006;1(1):11-25.

11. Rivera JÁ, De Cossío TG, Pedraza LS, Aburto TC, et al. Childhood and adolescent overweight and obesity in Latin America: a systematic review. Lancet Diabetes Endocrinol 2014;2(4):321-32.

12. Argentina. Ministerio de Salud. Encuesta Nacional de Nutrición y Salud. Documento de resultados 2007. [Accessed on: August 20,2015]. Available at: http:/ /www. msal.gov.ar/images/stories/bes/graficos/0000000257cnta08-ennys-documento-de-resultados-2007.pdf.

13. Ferrante D, Linetzky B, Ponce M, Goldberg L, et al. Prevalencia de sobrepeso, obesidad, actividad física y tabaquismo en adolescentes argentinos: Encuestas Mundiales de Salud Escolar y de Tabaco en Jóvenes, 20072012. Arch Argent Pediatr 2014;112(6):496-503.

14. Berghtein IR. Obesidad y sedentarismo en niños de 4 años que asisten a dos jardines de infantes de la ciudad de Río Grande, Tierra del Fuego, Argentina. Arch Argent Pediatr 2014;112(6):557-61.

15. Eyzaguirre F, Mericq V, Ceresa S, Youlton R, et al. Prevalencia de sobrepeso y obesidad en niños que se controlan en pediatría ambulatoria en Clínica Las Condes. Rev Chil Pediatr 2005;76(2):143-9.

16. Poston L. Maternal obesity, gestational weight gain and diet as determinants of offspring long term health. Best Pract Res Clin Endocrinol Metab 2012;26(5):627-39.

17. Öst A, Lempradl A, Casas E, Weigert M, et al. Paternal diet defines offspring chromatin state and intergenerational obesity. Cell 2014;159(6):1352-64.

18. McAllister EJ, Dhurandhar NV, Keith SW, Aronne LJ, et al. Ten putative contributors to the obesity epidemic. Crit Rev Food Sci Nutr 2009;49(10):868-913.

19. Elks CE,HeudeB, DeZegher F, BartonSJ, et al. Associations between genetic obesity susceptibility and early postnatal fat and lean mass: an individual participant meta-analysis. JAMA Pediatr 2014;168(12):1122-30.

20. Ahern D, Dixon E. Pediatric hypertension: a growing problem. Prim Care 2015;42(1):143-50.

21. Freedman DS, Dietz WH, Srinivasan SR, Berenson GS. The relation of overweight to cardiovascular risk factors among children and adolescents: the Bogalusa HeartStudy. Pediatrics 1999;103(6 Pt 1):1175-82.

22. Canapari CA, Hoppin AG, Kinane TB, Thomas BJ, et al. Relationship between sleep apnea, fat distribution, and insulin resistance in obese children. J Clin Sleep Med 2011;7(3):268-73.

23. Carroll CL, Bhandari A, Zucker AR, Schramm CM. Childhood obesity increases duration of therapy during severe asthma exacerbations. Pediatr Crit Care Med 2006;7(6):527-31.

24. Woo JG, Zeller MH, Wilson $\mathrm{K}$, Inge T. Obesity identified by discharge ICD-9 codes underestimates the true prevalence of obesity in hospitalized children. J Pediatr 2009;154(3):32731.

24. Green ED, Maffei M, Braden VV, Proenca R, etal. The human obese (OB) gene: RNA expression pattern and mapping on the physical, cytogenetic, and genetic maps of chromosome 7. Genome Res 1995;5(1):5-12.
25. Friedman JM, Halaas JL. Leptin and the regulation of body weight in mammals. Nature 1998;395(6704):763-70.

26. Zhang $Y$, Proenca R, Maffei M, Barone $M$, et al. Positional cloning of the mouse obese gene and its human homologue. Nature 1994;372(6505):425-32.

27. Tartaglia LA, Dembski M, Weng X, Deng N, et al. Identification and expression cloning of a leptin receptor, OB-R. Cell 1995;83(7):1263-71.

28. Tartaglia LA. The leptin receptor. J Biol Chem 1997;272(10):6093-6.

29. Reiterer EE, Sudi KM, Mayer A, Limbert-Zinterl C, et al. Changes in leptin, insulin and body composition in obese children during a weight reduction program. J Pediatr Endocrinol Metab 1999;12(6):853-62.

30. Kelly AS, Metzig AM, Schwarzenberg SJ, Norris AL, et al. Hyperleptinemia and hypoadiponectinemia in extreme pediatric obesity. Metab Syndr Relat Disord 2012;10(2):123-7.

31. Ozata M, Ozdemir IC, Licinio J. Human leptin deficiency caused by a missense mutation: multiple endocrine defects, decreased sympathetic tone, and immune system dysfunction indicate new targets for leptin action, greater central than peripheral resistance to the effects of leptin, and spontaneous correction of leptin-mediated defects. J Clin Endocrinol Metab 1999;84(10):3686-95.

32. Valle M, Martos R, Gascón F, Cañete R, et al. Low-grade systemic inflammation, hypoadiponectinemia and a high concentration of leptin are present in very young obese children, and correlate with metabolic syndrome. Diabetes Metab 2005;31(1):55-62.

33. Steinberger J,Steffen L, Jacobs DR Jr, Moran A, et al. Relation of leptin to insulin resistance syndrome in children. Obes Res 2003;11(9):1124-30.

34. XuH, Barnes GT, Yang Q, Tan G, etal. Chronicinflammation in fat plays a crucial role in the development of obesityrelated insulin resistance. J Clin Invest 2003;112(12):1821-30.

35. Wellen KE,HotamisligilGS. Obesity-induced inflammatory changes in adipose tissue. J Clin Invest 2003;112(12):1785-8.

36. Pieracci FM, Barie PS, Pomp A. Critical care of the bariatric patient. Crit Care Med 2006;34(6):1796-804.

37. LeeS,BachaF, GungorN, ArslanianSA.Waistcircumference is an independent predictor of insulin resistance in black and white youths. J Pediatr 2006;148(2):188-94.

38. Sinha R, Fisch G, Teague B, Tamborlane WV, et al. Prevalence of impaired glucose tolerance among children and adolescents with marked obesity. N C Med J 2002;346(11):802-10.

39. Singhal A, Farooqi IS, Cole TJ, O'Rahilly S, et al. Influence of leptin on arterial distensibility: a novel link between obesity and cardiovascular disease? Circulation 2002;106(15):191924.

40. PayneGA,TuneJD,KnudsonJD. Leptin-induced endothelial dysfunction: a target for therapeutic interventions. Curr Pharm Des 2014;20(4):603-8.

41. Wunsch R, De Sousa G, Toschke AM, Reinehr T. Intimamedia thickness in obese children before and after weight loss. Pediatrics 2006;118(6):2334-40.

42. Neville AL, BrownCV,WengJ,Demetriades D, etal.Obesity is an independent risk factor of mortality in severely injured blunt trauma patients. Arch Surg 2004;139(9):983-7.

43. Van Kerkhove MD, Vandemaele KA, Shinde V, JaramilloGutierrezG, etal. Risk factors for severe outcomes following 2009 influenza A (H1N1) infection: a global pooled analysis. PloS Med 2011;8(7):e1001053.

44. Goh VL, Wakeham MK, Brazauskas R, Mikhailov TA, et al. Obesity is not associated with increased mortality and morbidity in critically ill children. JPEN J Parenter Enteral Nutr 2013;37(1):102-8.

45. Brown CV, Neville AL, Salim A, Rhee P, et al. The impact 
of obesity on severely injured children and adolescents. J Pediatr Surg 2006;41(1):88-91.

46. Ross E, Burris A, Murphy JT. Obesity and outcomes following burns in the pediatric population. J Pediatr Surg 2014;49(3):469-73.

47. Srinivasan V, Nadkarni VM, Helfaer MA, Carey SM, et al. Childhood obesity and survival after in-hospital pediatric cardiopulmonary resuscitation. Pediatrics 2010;125(3): e481-8.

48. Yamamoto LG, Inaba AS, Young LL, Anderson KM. Improving length-based weight estimates by adding a body habitus (obesity) icon. Am J Emerg Med 2009;27(7):810-5.

49. Fisher DG, Schwartz PH, Davis AL. Pharmacokinetics of exogenous epinephrine in critically ill children. Crit Care Med 1993;21(1):111-7.

50. Steinberg C, Notterman DA. Pharmacokinetics of cardiovascular drugs in children. Inotropes and vasopressors. Clin Pharmacokinet 1994;27(5):345-67.

51. Berg MD, Banville IL, Chapman FW, Walker RG, et al. Attenuating the defibrillation dosage decreases postresuscitation myocardial dysfunction in a swine model of pediatric ventricular fibrillation. Pediatr Crit Care Med 2008;9(4):429-34.

52. López A, Sotomayor L, Álvarez MP, Céspedes P, et al. Rendimiento aeróbico en niños obesos de 6 a 10 años. Rev Chil Pediatr 2009;80(5):444-50.

53. KainJ, OlivaresS, RomoM,Leyton B, etal. Estadonutricional y resistencia aeróbica en escolares de educación básica: línea base de un Proyecto de Promoción de la Salud. Rev Med Chil 2004;132(11):1395-402.

54. Orgel E, Tucci J, Alhushki W, Malvar J, et al. Obesity is associated with residual leukemia following induction therapy for childhood B-precursor acute lymphoblastic leukemia. Blood 2014;124(26):3932-8.

55. Ford ES, Mokdad AH, Ajani UA. Trends in risk factors for cardiovascular disease among children and adolescents in the United States. Pediatrics 2004;114(6):1534-44.

56. Cook S, Auinger P, Huang TT. Growth curves for cardiometabolic risk factors in children and adolescents. J Pediatr 2009;155(3):S6.e15-26.

57. Juonala M, Magnussen CG, Berenson GS, Venn A, et al. Childhood adiposity, adult adiposity, and cardiovascular risk factors. N C Med J 2011;365(20):1876-85.

58. Khoury M, Manlhiot C, McCrindle BW. Role of the waist/ height ratio in the cardiometabolic risk assessment of children classified by body mass index. J Am Coll Cardiol 2013;62(8):742-51.

59. Arnaiz P, Grob F, Cavada G, Domínguez A, et al. La razón cintura estatura en escolares no varía con el género, la edad ni la maduración puberal. Rev Med Chil 2014;142(5):574-8.

60. Mardones F, Arnaiz P, Barja S, Giadach C, et al. Estado nutricional, síndrome metabólico y resistencia a la insulina en niños deSantiago, Chile. Nutr Hosp 2013;28(6):1999-2005.

61. Cook S, Weitzman M, Auinger P, Nguyen M, et al. Prevalence of a metabolic syndrome phenotype in adolescents: findings from the third National Health and Nutrition Examination Survey, 1988-1994. Arch Pediatr Adolesc Med 2003;157(8):821-7.

62. Weiss R, Dziura J, Burgert TS, TamborlaneWV, etal.Obesity and the metabolic syndrome in children and adolescents. N C Med J 2004;350(23):2362-74.

63. Clark L, Preissig C, Rigby MR, Bowyer F. Endocrine issues in the pediatric intensive care unit. Pediatr Clin North Am 2008;55(3):805-33.

64. Tiruvoipati R, Chiezey B, Lewis D, Ong K, et al. Stress hyperglycemia may not be harmful in critically ill patients with sepsis. J Crit Care 2012;27(2):153-8.
65. Branco RG, Xavier L, Garcia PC, Piva JP, et al. Prospective operationalization and feasibility of a glycemic control protocol in critically ill children. Pediatr Crit Care Med 2011;12(3):265-70.

66. Carchman RM, Dechert-Zeger M, Calikoglu AS, Harris BD. A new challenge in pediatric obesity: pediatric hyperglycemic hyperosmolar syndrome. Pediatr Crit Care Med 2005;6(1):20-4.

67. Lin JJ, McKenney DW, Price C, Morrison RR, et al. Continuous venovenous hemodiafiltration in hypernatremic hyperglycemic nonketotic coma. Pediatr Nephrol 2002;17(11):969-73.

68. American Diabetes Association. Hyperglycemic crises in patients with diabetes mellitus. Diabetes Care 2001;24(11):1988-96.

69. Flynn J. The changing face of pediatric hypertension in the era of the childhood obesity epidemic. Pediatr Nephrol 2013;28(7):1059-66.

70. McNiece KL, Poffenbarger TS, Turner JL, Franco KD, et al. Prevalence of hypertension and pre-hypertension among adolescents. J Pediatr 2007;150(6):640-4.

71. GundogduZ. Relationship between BMIand blood pressure in girls and boys. Public Health Nutr 2008;11(10):1085-8.

72. Aggoun Y, Farpour-Lambert NJ, Marchand LM, Golay E, et al. Impaired endothelial and smooth muscle functions and arterial stiffness appear before puberty in obese children and are associated with elevated ambulatory blood pressure. Eur Heart J 2008;29(6):792-9.

73. Maggio AB, Aggoun Y, Marchand LM, Martin XE, et al. Associations among obesity, blood pressure, and left ventricular mass. J Pediatr 2008;152(4):489-93.

74. Rabbia F, Silke B, Conterno A, Grosso T, et al. Assessment of cardiac autonomic modulation during adolescent obesity. Obes Res 2003;11(4):541-8.

75. Feber J, Ruzicka M, Geier P, Litwin M. Autonomic nervous system dysregulation in pediatric hypertension. Curr Hypertens Rep 2014;16(5):426.

76. Singh D, Akingbola O, Yosypiv I, El-Dahr S. Emergency management of hypertension in children. Int J Nephrol 2012;2012:420247.

77. Constantine E, Merritt C. Hypertensive emergencies in children: identification and management of dangerously high blood pressure. Minerva Pediatr 2009;61(2):175-84.

78. Li AM, Chan D, Wong E, Yin J, et al. The effects of obesity on pulmonary function. Arch Dis Child 2003;88(4):361-3.

79. Davidson WJ, Mackenzie-Rife KA, Witmans MB, Montgomery MD, et al. Obesity negatively impacts lung function in children and adolescents. Pediatr Pulmonol 2014;49(10):1003-10.

80. Assuncao SN, Daltro $\mathrm{CH}$, Boa Sorte NC, Ribeiro Júnior $\mathrm{Hda} \mathrm{C}$, et al. Lung function in the absence of respiratory symptoms in overweight children and adolescents. J Bras Pneumol 2014;40(2):134-41.

81. Khan S, Little J, Chen Y. Relationship between adiposity and pulmonary function in school-aged Canadian children. Pediatr Allergy Immunol Pulmonol 2014;27(3):126-32.

82. Bailey KA. Special considerations in the critically ill morbidly obese child. Crit Care Clin 2010;26(4):699-702.

83. Scherrer PD, Mallory MM, Cravero JP, Lowrie L, et al. The impact of obesity on pediatric procedural sedation-related outcomes: results from the Pediatric Sedation Research Consortium. Paediatr Anaesth 2015;25(7):689-97.

84. Ray RM, Senders CW. Airway management in the obese child. Pediatr Clin Noth Am 2001;48(4):1055-63.

85. Malhotra A, Hillman D. Obesity and the lung: 3. Obesity, respiration and intensive care. Thorax 2008;63(10):925-31.

86. DeaneS, Thomson A. Obesity and the pulmonologist. Arch 
Dis Child 2006;91(2):188-91.

87. Tait AR, Voepel-Lewis T, Burke C, Kostrzewa A, et al. Incidence and risk factors for perioperative adverse respiratory events in children who are obese. Anesthesiology 2008;108(3):375-80.

88. Nafiu OO, Reynolds PI, Bamgbade OA, Tremper KK, et al. Childhood body mass index and perioperative complications. Paediatr Anaesth 2007;17(5):426-30.

89. El-Solh AA. Clinical approach to the critically ill, morbidly obese patient. Am J Respir Crit Care Med 2004;169(5):557-61.

90. Juvin P, Lavaut E, Dupont H, Lefevre P, et al. Difficult tracheal intubation is more common in obese than in lean patients. Anesth Analg 2003;97(2):595-600.

91. Brodsky JB, Lemmens HJ, Brock-Utne JG, Vierra M, et al. Morbid obesity and tracheal intubation. Anesth Analg 2002;94(3):732-6.

92. Nafiu OO, Burke CC, Gupta R, Christensen R, et al. Association of neck circumference with perioperative adverse respiratory events in children. Pediatrics 2011;127(5):e1198-205.

93. Lang JE, Feng H, Lima JJ. Body mass index-percentile and diagnostic accuracy of childhood asthma. J Asthma 2009;46(3):291-9.

94. Carroll CL, Uygungil B, Zucker AR, Schramm CM. Identifying an at-risk population of children with recurrent near-fatal asthma exacerbations. J Asthma 2010;47(4):460-4.

95. Carroll CL, Stoltz P, Raykov N, Smith SR, et al. Childhood overweight increases hospital admission rates for asthma. Pediatrics 2007;120(4):734-40.

96. Guler N, Kirerleri E, Ones U, Tamay Z, et al. Leptin: does it have any role in childhood asthma? J Allergy Clin Immunol 2004;114(2):254-9.

97. Arabi YM, Dara SI, Tamim HM, Rishu AH, et al. Clinical characteristics, sepsis interventions and outcomes in the obese patients with septic shock: an international multicenter cohort study. Crit Care 2013;17(2):R72.

98. Blanco-Quirós A, Casado-Flores J, Arranz E, Garrote JA, et al. Influence of leptin levels and body weight in survival of children with sepsis. Acta Paediatr 2002;91(6):626-31.

99. Falagas ME, Kompoti M. Obesity and infection. Lancet Infect Dis 2006;6(7):438-46.

100.101.Wang HE, Griffin R, Judd S, Shapiro NI, et al. Obesity and risk of sepsis: a population-based cohort study. Obesity (Silver Spring) 2013;21(12):E762-9.
101.Kaplan JM, Nowell M, Lahni P, O'Connor MP, et al. Short-term high fat feeding increases organ injury and mortality after polymicrobial sepsis. Obesity (Silver Spring) 2012;20(10):1995-2002.

102.Siegl D, Annecke T, Johnson BL 3rd, Schlag C, et al. Obesity-induced hyperleptinemia improves survival and immune response in a murine model of sepsis. Anesthesiology 2014;121(1):98-114.

103.Wang Y, Chen X, Song Y, Caballero B, et al. Association between obesity and kidney disease: a systematic review and meta-analysis. Kidney Int 2008;73(1):19-33.

104. Kambham N, Markowitz GS, Valeri AM, Lin J, et al. Obesityrelated glomerulopathy: an emerging epidemic. Kidney Int 2001;59(4):1498-509.

105.Iseki K, Ikemiya Y, Kinjo K, Inoue T, et al. Body mass index and the risk of development of end-stage renal disease in a screened cohort. Kidney Int 2004;65(5):1870-6.

106.Sowers JR. Metabolic risk factors and renal disease. Kidney Int 2007;71(8):719-20.

107.Ejerblad E, Fored CM, Lindblad P, Fryzek J, et al. Obesity and risk for chronic renal failure. J Am Soc Nephrol 2006;17(6):1695-702.

108.Tomaszewski M, Charchar FJ, Maric C, McClure J, et al. Glomerular hyperfiltration: a new marker of metabolic risk. Kidney Int 2007;71(8):816-21.

109. Kelly AS, Steinberger J, Kaiser DR, Olson TP, etal. Oxidative stress and adverse adipokine profile characterize the metabolic syndrome in children. J Cardiometab Syndr 2006;1(4):248-52.

110. Alicic RZ, Patakoti R, Tuttle KR. Direct and indirect effects of obesity on the kidney. Adv Chronic Kidney Dis 2013;20(2):121-7.

112. Whaley-ConnellAT,ChowdhuryNA,HaydenMR,StumpCS, et al. Oxidative stress and glomerular filtration barrier injury: role of the renin-angiotensin system in the Ren2 transgenic rat. Am J Physiol Renal Physiol 2006;291(6):F1308-14.

113.Felizardo RJ, da Silva MB, Aguiar CF, Câmara NO. Obesity in kidney disease: a heavyweight opponent. World JNephrol 2014;3(3):50-63.

114.Wolf G, Hamann A, Han DC, Helmchen U, et al. Leptin stimulates proliferation and TGF-beta expression in renal glomerular endothelial cells: potential role in glomerulosclerosis. Kidney Int 1999;56(3):860-72.

115. Gorbachinsky I, AkpinarH,Assimos DG. Metabolicsyndrome and urologic diseases. Rev Urol 2010;12(4):e157-80. 